BMC

Complementary \& Alternative Medicine

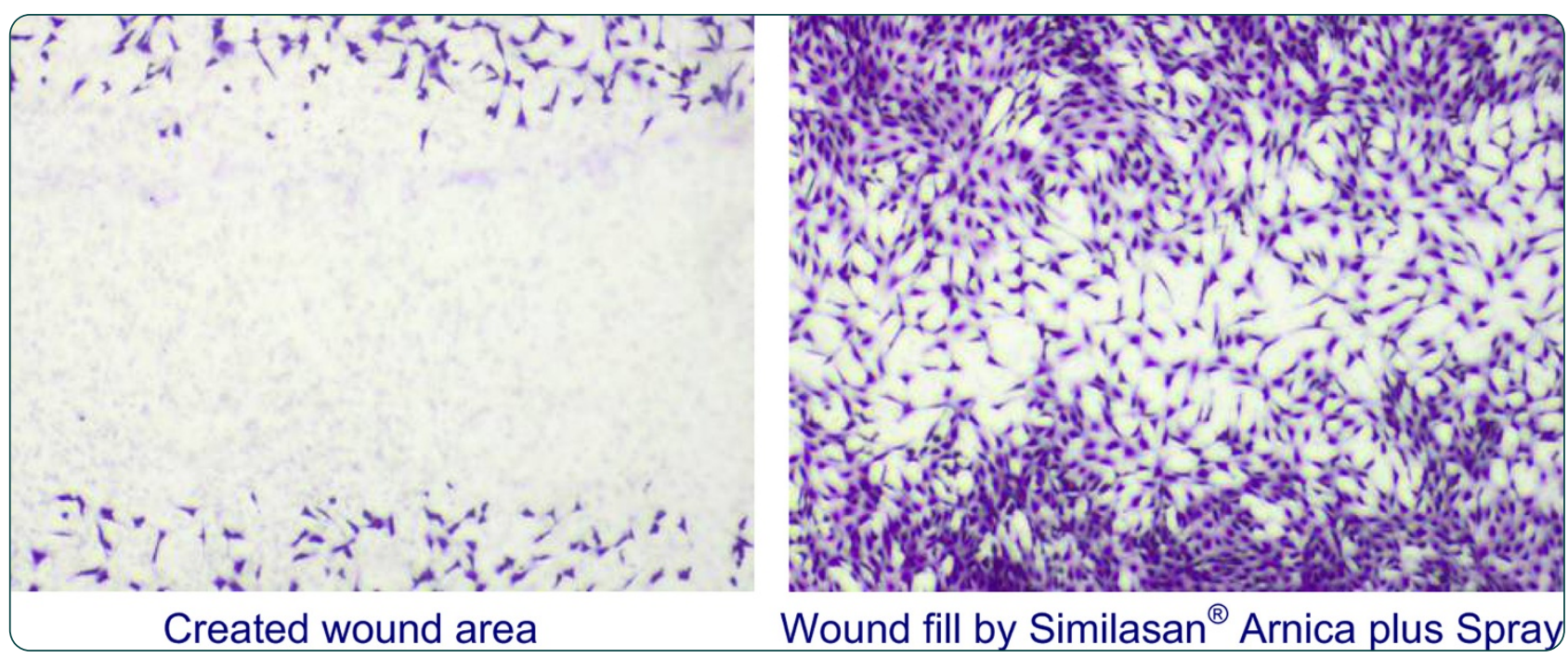

\title{
A homeopathic remedy from arnica, marigold, St. John's wort and comfrey accelerates in vitro wound scratch closure of NIH $3 \mathrm{~T} 3$ fibroblasts
}

Hostanska et al. 


\title{
A homeopathic remedy from arnica, marigold, St. John's wort and comfrey accelerates in vitro wound scratch closure of $\mathrm{NIH} 3 \mathrm{~T} 3$ fibroblasts
}

\author{
Katarina Hostanska ${ }^{{ }^{*}}$, Matthias Rostock ${ }^{1,2}$, Joerg Melzer ${ }^{1}$, Stephan Baumgartner ${ }^{3,4,5}$ and Reinhard Saller ${ }^{1}$
}

\begin{abstract}
Background: Drugs of plant origin such as Arnica montana, Calendula officinalis or Hypericum perforatum have been frequently used to promote wound healing. While their effect on wound healing using preparations at pharmacological concentrations was supported by several in vitro and clinical studies, investigations of herbal homeopathic remedies on wound healing process are rare. The objective of this study was to investigate the effect of a commercial low potency homeopathic remedy Similasan ${ }^{\circledR}$ Arnica plus Spray on wound closure in a controlled, blind trial in vitro.

Methods: We investigated the effect of an ethanolic preparation composed of equal parts of Arnica montana $4 x$, Calendula officinalis 4x, Hypericum perforatum 4x and Symphytum officinale 6x (0712-2), its succussed hydroalcoholic solvent (0712-1) and unsuccussed solvent (0712-3) on NIH 3 T3 fibroblasts. Cell viability was determined by WST-1 assay, cell growth using BrdU uptake, cell migration by chemotaxis assay and wound closure by CytoSelect TMW Wound Healing Assay Kit which generated a defined "wound field". All assays were performed in three independent controlled experiments.
\end{abstract}

Results: None of the three substances affected cell viability and none showed a stimulating effect on cell proliferation. Preparation (0712-2) exerted a stimulating effect on fibroblast migration (31.9\%) vs $14.7 \%$ with succussed solvent $(0712-1)$ at 1:100 dilutions $(p<0.001)$. Unsuccussed solvent $(0712-3)$ had no influence on cell migration (6.3\%; $p>0.05)$. Preparation (0712-2) at a dilution of $1: 100$ promoted in vitro wound closure by $59.5 \%$ and differed significantly $(p<0.001)$ from succussed solvent $(0712-1)$, which caused $22.1 \%$ wound closure.

Conclusion: Results of this study showed that the low potency homeopathic remedy (0712-2) exerted in vitro wound closure potential in $\mathrm{NIH} 3 \mathrm{~T} 3$ fibroblasts. This effect resulted from stimulation of fibroblasts motility rather than of their mitosis.

Keywords: Wound healing, 3T3 fibroblasts, Homeopathic remedy, Arnica, Calendula, Hypericum, Symphytum

\section{Background}

Wound healing plays a central role for the physical health of the human being. The search for wound healing agents is one of the oldest challenges in medicine, as the mechanism involved in the repair of damaged tissue is yet not fully understood. Skin wound healing is a dynamic process in which different cell types, such as fibroblasts, leukocytes, monocytes/tissue macrophages as

\footnotetext{
* Correspondence: katarinahostanska@hotmail.com

1 Institute for Complementary Medicine, University Hospital Zurich, Raemistrasse 100, Zurich 8091, Switzerland

Full list of author information is available at the end of the article
}

well as endothelial and epidermal cells cooperate to restore the affected skin. This highly coordinated process includes a series of both simultaneous and overlapping phases which promote an efficient healing [1,2].

Since ancient times herbal medicines have been widely used all over the world and have been well recognized by the physicians and patients for their therapeutic value.

Various extracts from numerous plants that have been used in wound care, including traditional European plants such as arnica, marigold and St. John's wort have been reported to accelerate the wound healing process [3-10]. However, in these studies herbal preparations at

\section{Ciomed Central}

(c) 2012 Hostanska et al.; licensee BioMed Central Ltd. This is an Open Access article distributed under the terms of the Creative Commons Attribution License (http://creativecommons.org/licenses/by/2.0), which permits unrestricted use, distribution, and reproduction in any medium, provided the original work is properly cited. 
pharmacological concentrations were used in humans as well as in animals or in in vitro experiments.

Homeopathy is a therapeutic method based on the empiric law of similars with the hypothesis, that a given substance can cure in a diseased person the symptoms that it produces or causes in a healthy person [11]. There are some contradictory results regarding the effect of homeopathic remedies in low concentrations on wound healing. In several animal and human studies a wound healing activity has been observed [12-15]. On the other side no effect could be found in other trials $[11,16,17]$. In vitro studies on the wound healing of remedies at homeopathic dilutions are scarce [18].

Therefore, the objective of our study was to evaluate, through an in vitro model in blinded manner, the efficacy of a commercial homeopathic remedy, Similasan ${ }^{\circledR}$ Arnica plus Spray consisting of arnica, marigold, St. John's wort and comfrey. It is used to treat injuries such as sprains, bruises, contusions, haematomas, muscle soreness or pain following operations and bone fractures. We used the well-established in vitro scratch assay in mouse NIH 3T3 fibroblasts, that mimics the behaviour of these cells during migration in vivo and is compatible with microscopy and cell imaging software $[8,19]$.

\section{Methods}

\section{Preparation of Similasan ${ }^{\circledR}$ Arnica plus Spray and controls}

Similasan $^{\odot}$ Arnica plus Spray is an over-the-counter homeopathic preparation composed of extracts of four plants that have been moderately diluted. The potency level of individual components is $4 \mathrm{x}$ (arnica, St. John's wort, marigold) and 6x (comfrey). The homeopathic preparation was potentized (diluted in the ratio 1:10) at Similasan AG (Jonen, Switzerland), starting from the single alcoholic potencies arnica 1x (Arnica montana L.), marigold $1 \mathrm{x}$ (Calendula officinalis L.), St. John's wort $1 \mathrm{x}$ (Hypericum perforatum L.) and comfrey 3x (Symphytum officinale L.) manufactured by Herbamed (Buehler, Switzerland), following the German Homoeopathic Pharmacopoeia (GHP1) [20] and corresponding descriptions 4a for arnica, 3a for marigold and St. John's wort, and 2a for comfrey. The four components were potentized separately up to 3x (Arnica, Calendula, Hypericum) and 5x (Symphytum), respectively. The last potentization step was performed with all four components combined at equal quantities. Similasan Arnica plus Spray (lot number 10079) contained $2.80 \mathrm{mg}$ Arnica, $0.279 \mathrm{mg}$ Calendula, $0.864 \mathrm{mg}$ Hypericum and $7.95 \mu \mathrm{g}$ Symphytum dry herbs in $100 \mathrm{~g}$ remedy. In all assays comparison was made between solvent (0712-1) serially succussed as was done with the active remedy (0712-2) but without the initial addition of single components. Unsuccussed control containing 22\% alcoholic solution in distilled water (0712-3) was also used in the present study.

\section{Blinding procedure}

Both homeopathic remedy and succussed placebo at volume of $20 \mathrm{ml}$ in twenty dark glass ampoules were coded by the producer $0712-2(1-20)$ and $0712-1$ (1-20), respectively. Study was designed in double - blind manner. Blinded investigators re-coded the ampoules again. Unsuccussed solvent (0712-3) was unblinded. Three independent sets of experiments were performed for each assay.

\section{Cell line and culture conditions}

Mouse NIH 3T3 fibroblasts (ATCC, Rockville, USA) were kindly supplied by Dr. E. Fassler (University of Applied Sciences Northwestern Switzerland, Muttenz, Switzerland) and cultured in Dulbecco's modified Eagle's medium (DMEM) supplemented with 5\% fetal calf serum (FCS), $4 \mathrm{mM} \mathrm{L} \mathrm{-} \mathrm{glutamine,} \mathrm{1 \%} \mathrm{penicillin/}$ streptomycin under a fully humidified atmosphere containing $5 \% \mathrm{CO}_{2}$ at $37^{\circ} \mathrm{C}$. For experiments, cells were collected from subconfluent monolayers with trypsin/ EDTA. Cell viability was higher as $95 \%$ using trypan blue dye exclusion staining. The studies were carried out using cells from passages $3-8$ in DMEM medium containing $2 \%$ FCS. In all experiments untreated cells were used as negative controls. All cell culture reagents and recombinant human epidermal growth factor (EGF) used as positive control in the chemotaxis migration assay were obtained from Sigma (Buchs, Switzerland).

\section{WST-1 cell viability assay}

The effect of substances 0712-1, 0712-2 and 0712-3 on the viability of NIH 3T3 cells was determined after 24 and $48 \mathrm{~h}$ treatment using WST-1 assay as previously described [21]. Briefly, NIH 3T3 cells were dispensed in 96-well flatbottomed microtiter plates at a density of $1 \times 10^{4}$ cells/ well and incubated with tested substances at 1/10, 1/100 and $1 / 1000$ dilutions for $20 \mathrm{~h}$ and $44 \mathrm{~h}$ followed for $4 \mathrm{~h}$ with a tetrazolium salt WST-1 (4-[3-(4-iodophenyl)-2(4-nitrophenyl)-2 H-5-tetrazolio]-1,3-benzene disulfonate) from Roche Diagnostica (Rotkreuz, Switzerland). The cleavage of WST-1 to formazan by metabolically active cells was quantified by scanning the plates at $450 \mathrm{~nm}$ and $650 \mathrm{~nm}$ reference wavelength in a microtiter plate reader. Test medium was used as background control. Three independent sets of experiments performed in triplicates were evaluated. The effect of vehicle ethanol on the NIH 3T3 cell viability at concentration of $0.5 \%$ and $1 \%$ was tested in parallel. Viability of treated cells was normalized to the untreated control cells.

\section{5-Bromo-2-deoxyuridine (BrdU) incorporation}

NIH 3T3 cells were precultured for two days in DMEM medium supplemented with 1\% FCS and then seeded at a density of $1 \times 10^{4}$ into a 96 wells microtiter plate and cultured in the test medium (DMEM without FCS) in a 
presence or absence of tested substances for $48 \mathrm{~h}$. As positive control DMEM with 5\% FCS was used. Solvent ethanol $(0.5 \% \mathrm{v} / \mathrm{v})$ was tested in parallel. BrdU is a DNA specific analog of $\left[{ }^{3} \mathrm{H}\right]$ thymidine. Therefore for the quantification of cell proliferation the BrdU Cell Proliferation Assay from Oncogene Research Products (San Diego, USA) a non-isotopic enzyme immunoassay [22] was used according to manufacturer's instructions. In brief, during the final $24 \mathrm{~h}$ of culture $10 \mu \mathrm{M}$ BrdU was added to the wells and BrdU was incorporated into DNA of dividing cells. BrdU incorporation was then evaluated by measuring the absorbance at 450-540 nm according to the manufacturer's protocol. Experiments in triplicate repeated three times were evaluated. Two types of controls, only culture medium as blank and wells with unlabelled cells as background were also set.

\section{Transwell chamber migration assay}

To investigate the migration of cells we used the most commonly applied in vitro assay, namely the transwell chamber assay using culture inserts with a $8 \mu \mathrm{m}$ pore-size filter barrier from BD Biosciences (Bedford, USA) [23]. $\mathrm{NIH} 3 \mathrm{~T} 3$ cell suspensions $\left(3 \times 10^{4}\right.$ cells/filter $)$ with or without substances $0712-1,0712-2$ and $0712-3$ at 1/10, 1/100 and $1 / 1000$ dilutions were added to the upper compartment whereas the bottom wells were immediately filled with conditioned medium (10\% FCS) of fibroblasts as chemoattractant. As positive control EGF (2 ng/ml) was used. After $24 \mathrm{~h}$ of incubation, the non-migrated cells in the upper chamber were gently scraped, and the adherent cells present on the lower surface of the insert were fixed and stained with $0.5 \%$ crystal violet in $20 \%$ methanol. Quantification of migrated cells was determined after extraction of adhesive cells with 30\% acetic acid and the absorbance of the cell lysate was scanned by a microplate reader at $540 \mathrm{~nm}$. Each migration experiment was carried out in duplicate and repeated three times. Data are expressed as percent of migration through the cell culture inserts relative to the untreated controls.

\section{In vitro wound healing (scratch) assay}

The effect of substances 0712-1, 0712-2 and 0712-3 at 1/ 100 and 1/1000 dilutions on wound closure was investigated with CytoSelect ${ }^{\mathrm{Ts}}$ Wound Healing Assay Kit (Cell Biolabs, Inc., San Diego, USA). NIH 3T3 fibroblasts $\left(25 \times 10^{3} /\right.$ $500 \mu \mathrm{l})$ in DMEM containing 5\% FCS were seeded into 24wells tissue culture plate containing proprietary treated inserts in the plate wells with their "wound field" aligned in the same direction and incubated for $24 \mathrm{~h}$ to allow the cells adhere and reach the 60-80\% confluence. After removing the inserts from the wells the medium was carefully aspired and wells were washed with test medium (DMEM containing $2 \%$ FCS) to remove dead cells and debris. Finally, the cells were treated with different concentrations of tested compounds for further 24 hours. Migration into the wound field was determined by using manual fixing with cell stain solution according to manufacturer's instructions. Representative images focused on the center of the wound field were photographed. Microscopic imaging of wound closure was analysed using CellD software [24]. Three sets of experiments in duplicates were performed. The influence of compounds on wound closure was compared to untreated control. As positive control DMEM with 5\% FCS was used. Density of cells in wells without created wound area (confluent area) was used as $100 \%$ wound closure.

Experiments were evaluated using following formula:

Wound closure $(\%)=[$ test compound $(\%)-$ untreated control (\%))/ (confluent area (\%) - untreated control $(\%))] \times 100$

\section{Statistical analyses}

For each parameter, average values with standard deviations (mean $\pm \mathrm{SD}$ ) were calculated. Transwell migration assay data were analysed by a two-way ANOVA with the independent factors experiment (1-3) and treatment ( $\mathrm{n}=11$ parameters) followed by Bonferroni post-hoc tests. Monolayer wound healing assay data were analysed by a two-way ANOVA with the independent factors experiment $(1-3)$ and treatment $(n=6$ parameters) followed by Bonferroni post-hoc tests. Differences were considered significant if $\mathrm{p}<0.05$. Statistical analysis was performed with Statistica 6.0 (Statsoft Inc., Tulsa, USA).

\section{Results and discussion}

\section{Cell viability and proliferation response}

Cell-based assays can be influenced by cytotoxic effects resulting in false negative results. Therefore, the effects of substances $0712-1,0712-1$ and $0712-3$ on NIH 3T3 cell viability were studied. For the assessment of cell survival the WST-1 assay was used, which measures the dehydrogenase activity of viable cells by the cleavage of the tetrazolium salt to formazan in viable cells. Because of possible interference of natural substances with another tetrazolium salt MTT, we first measured the direct reductive potential of all substances in a cell-free system. None of them differred from the blank (medium only). Absorbance values (450-650 nm) for substances were between 0.102-0.113 in comparison to 0.111 of blank value. Cell survival was estimated after $24 \mathrm{~h}$ and $48 \mathrm{~h}$ treatment according to the following criteria. Cultures with more than $90 \%$ viable cells were considered to be unaffected, $80-90 \%$ as modestly affected, and values of less than $80 \%$ viable cells were ascribed to cytotoxic effects of the compound. Considering the above-mentioned criteria, no cytotoxicity of substances was observed. Substances 0712-1 (succussed solvent) and 0712-2 (remedy) exerted a modest effect at the 1:10 dilution, which could be related to the concentration of ethanol of about $2 \%$ at this dilution level (Table 1 ). The vehicle 
Table 1 Effect of substances on NIH $3 \mathrm{~T} 3$ cell viability and cell growth

\begin{tabular}{|c|c|c|c|c|}
\hline \multirow[t]{2}{*}{ Substance } & \multirow[t]{2}{*}{ Dilution } & \multicolumn{2}{|c|}{ Cell survival [\%] } & \multirow{2}{*}{$\frac{\text { Cell growth [\%] }}{48 \mathrm{~h}}$} \\
\hline & & $24 \mathrm{~h}$ & $48 \mathrm{~h}$ & \\
\hline $0712-1$ & $1 / 10$ & $83.3 \pm 1.2$ & & $83.0 \pm 2.7$ \\
\hline 0712-1 & $1 / 100$ & $92.3 \pm 0.6$ & $92.3 \pm 3.2$ & $86.7 \pm 2.5$ \\
\hline 0712-1 & $1 / 1000$ & $98.7 \pm 1.5$ & $95.0 \pm 2.7$ & $93.7 \pm 0.6$ \\
\hline $0712-2$ & $1 / 10$ & $83.0 \pm 1.0$ & $82.3 \pm 0.6$ & $81.3 \pm 2.1$ \\
\hline $0712-2$ & $1 / 100$ & $92.7 \pm 3.8$ & $93.0 \pm 0.2$ & $90.7 \pm 3.2$ \\
\hline $0712-2$ & $1 / 1000$ & $93.3 \pm 1.2$ & $95.7 \pm 1.2$ & $96.0 \pm 1.0$ \\
\hline $0712-3$ & $1 / 10$ & $97.0 \pm 3.0$ & $93.3 \pm 0.6$ & $91.3 \pm 1.5$ \\
\hline $0712-3$ & $1 / 100$ & $99.3 \pm 4.9$ & $96.0 \pm 2.0$ & $94.0 \pm 2.0$ \\
\hline $0712-3$ & $1 / 1000$ & $103.7 \pm 2.1$ & $99.7 \pm 1.2$ & $95.0 \pm 2.0$ \\
\hline \multirow[t]{2}{*}{ pos.ctrl } & DMEM & n.d. & n.d. & $140.5 \pm 9.5$ \\
\hline & $5 \%$ FCS & & & \\
\hline
\end{tabular}

Exerted effects of substances were standardized to untreated controls. n.d.- not detected. Results are presented as average \pm SD from three independent experiments performed in triplicates. Cell survival was assessed with the WST-1 assay, cell growth with the BrdU assay.

controls at concentrations of $0.5 \%$ and $1 \%$ did not affect the viability of NIH 3T3 cells. Cell survival was higher than $95 \%$ at both concentrations. Usually ethanol concentration up to $1-2 \%$ does not affect the survival of most cell lines. However, the cytotoxicity of ethanol on different cell cultures at higher concentration is well known [25]. Survival of cells after $48 \mathrm{~h}$ culture was equal to survival after $24 \mathrm{~h}$ (Table 1 ). The $48 \mathrm{~h}$ cell viability was estimated also, because the effect of substances on the cell proliferation was measured after two days incubation.

In living humans and animals, the wound healing process includes the following phases: blood coagulation, inflammation, cell proliferation, cell migration, lesion contraction, and remodelling. All these phases overlap to promote efficient healing [2]. At first, we chose to carry out the proliferative effect of substances on NIH 3T3 fibroblasts. The proliferative response was based on a quantitative analysis of the percentage of cells staining positive for BrdU incorporation. As positive control DMEM with 5\% FCS was used, which caused a proliferation stimulation of $40.5 \pm 9.5 \%$. Absorbance value for the positive control was $1.793 \pm 0.23$ in comparison to $1.277 \pm 0.15$ for the negative control. The levels of proliferation found in response to substances $0712-1$ and $0712-2$ were compared to those found using $0 \%$ FCS as negative control. No proliferation effect could be found with both substances for the cells at any concentration (Table 1). Growth of cells was modestly reduced by about $10 \%$ and by about $5 \%$ at $1: 100$ and 1:1000 dilutions of both substances, respectively. These results could be in accordance with findings, that the high level of cellular confluence down-regulates proliferation [26]. The down-regulation of about 17\% (1.06 absorbance value) of the cells was found at the dilutions of 1:10, and could be ascribed to the effect of $2 \%$ ethanol as shown by the survival experiments. The results of cells survival by measuring dehydrogenase activity in viable cells correlated well with the BrdU incorporation into DNA of dividing cells.

\section{Chemotactic migration response}

The proliferative phase is characterized by fibroblast migration followed by angiogenesis and re-epithelization. Cell migration is a process that is essential for tissue repair. Fibroblasts play a key role in dermal wound repair, since they have the ability to migrate and close wounds [2]. For

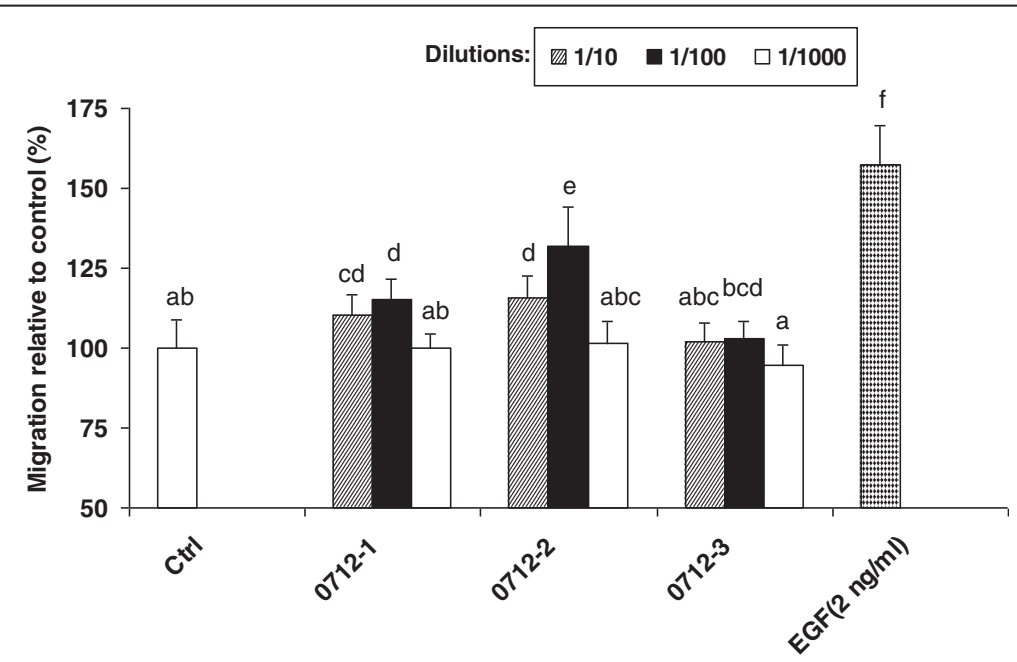

Figure 1 Effect of substances on fibroblasts migration. Migration of NIH 3 T3 cells (30000/filter) by 0712-1(succussed solvent), 0712-2 (remedy) and 0712-3 (unsuccussed solvent) after $24 \mathrm{~h}$ was measured by chemotaxis using 10\% FCS as chemoatractant and are expressed as percentages normalized to the untreated control value. As positive control $2 \mathrm{ng} / \mathrm{ml}$ EGF was used. Means \pm SD from three independent experiments performed in duplicates are presented. All values with different letters are statistically different $(p<0.05)$. 
studying the migration and wound healing activity we used the in vitro skin equivalent model on an established cell lines mouse NIH 3T3 [19,27]. Soluble growth factors are essential for the regulation of cellular events involved in wound healing, i.e. inter alia migration [28]. Chemotaxis was measured using directional fibroblasts migration toward $10 \%$ FCS as chemoattractant in modified Boyden chamber. EGF (2 ng/ml) was chosen as positive control, which exerted a preferential effect on cell migration, rarely accompanied by any effect of cell proliferation [29]. Both preparation 0712-1 and 0712-2 stimulated cell locomotion as shown in Figure 1. In comparison to untreated control a significant difference with 0712-1 $(\mathrm{p}<0.01)$ and $0712-2(\mathrm{p}<0.001)$ at a dilution of $1: 100$ was observed in three independent experiments. Migration of cells was stimulated by $14.7 \%$ with $0712-1$ and $31.9 \%$ with $0712-2$. Absorbance value of untreated control (1.092) was elevated to 1.253 and 1.440 by substances $0712-1$ and $0712-2$, respectively. Substances at 1:10 dilution caused an enhancement of $10.5 \%(0712-1)$ to absorbance value 1.207 and $15.5 \%(0712-2)$ to an absorbance value of 1.262 . The highest dilution (1:1000) of both substances did not exert any effect on cell migration. NIH 3T3 cell motility was not influenced by any dilution of ethanol control 0712-3. A negligible elevation of $6.3 \%$ was measured with absorbance value of 1.161 . EGF accelerated migration of cells by $57.5 \%$ to a 1.720 absorbance value. The differences between substance 0712-1 and 0712-2 showed statistical significance for the dilution 1:100 $(\mathrm{p}<0.001)$. Furthermore, remedy (0712-2) differed from 0712-3 significantly for the dilutions $1: 10$ and $1: 100$ ( $\mathrm{p}<0.01$ and $\mathrm{p}<0.001$, respectively). It was surprising, that the substance 0712-1 (succussed solvent) caused a modest enhancement on cell motility, but it was already observed that a succussed solvent exerted biological effects [30]. In spite that we did not find any proliferation effect of substances $0712-1$ and $0712-2$, the NIH 3T3 cells exposed to these substances showed an increasing migration. It was reported that the migrationpromoting activity differs from growth-promoting activity [31] and e.g. EGF caused acceleration of cell migration, without an effect on proliferation rate [29]. Similarly, extracts from Hypericum perforatum showed wound healing effect related to its promoting effect on 3T3 fibroblast migration without affecting the cell growth [10]. Cellular proliferation response may not accurately reflect the overall wound healing response. The results of increased cell migration by substances provided confidence for the wound healing experiments.

\section{Effectiveness of substances on wound closure}

The most important clinical endpoint in wound management is wound closure or $100 \%$ epithelization. We used the in vitro wound-healing scratch assay in NIH 3T3 fibroblasts which mimics cell migration during wound healing in vivo. Specifically, this model assessed cellular wound fill, the "net effect" of all cellular events contributing to the in vitro wound healing process, and has been proven as a valuable tool to obtain first insights into how preparations can positively influence the wound closure $[8,19]$. Further we used a kit, which overcomes the disadvantage of common scratch wound assays lacking a defined wound area by providing proprietary treated inserts that generate a defined wound field. After the wound field was created, NIH 3T3 cells were exposed for $24 \mathrm{~h}$ to succussed solvent (0712-1), remedy (0712-2) and unsuccussed solvent (0712-3) in a dilution of $1: 100$ and $1: 1000$. As positive control we used DMEM with 5\% FCS, because the density of cells was too high at $10 \%$ FCS. Migration of cells into the wound was compared to untreated control in DMEM with $2 \%$ FCS. Only $4.9 \pm 1.3 \%$ migrated into the wounded area after $24 \mathrm{~h}$ in comparison to time zero (Figure 2A).

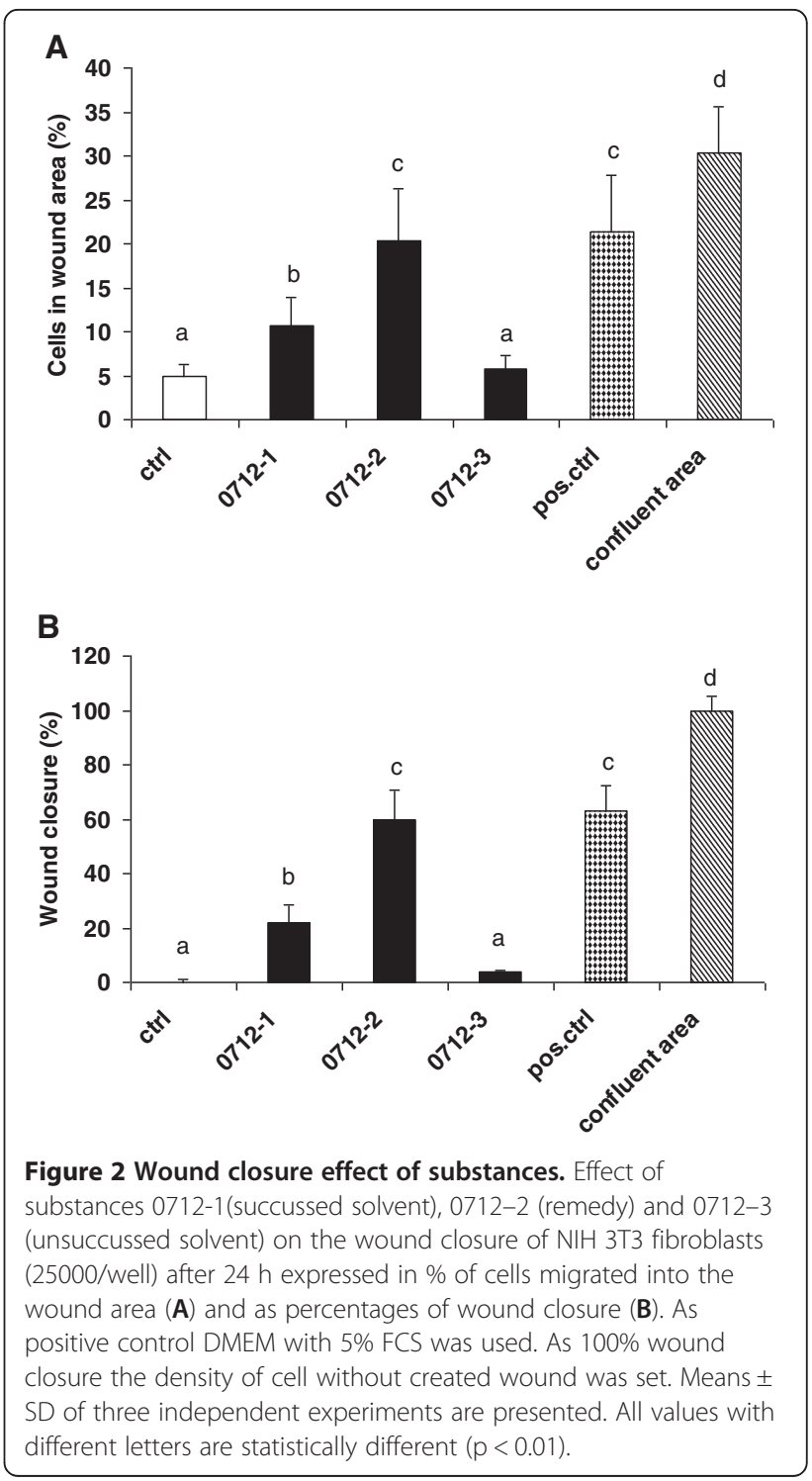



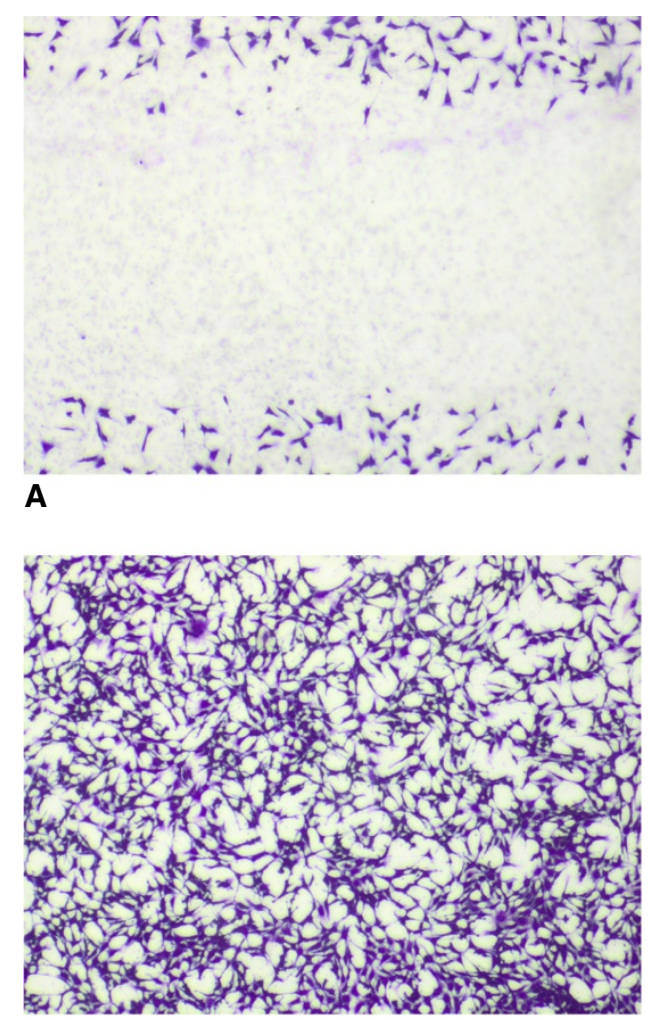
C: $100 \%$
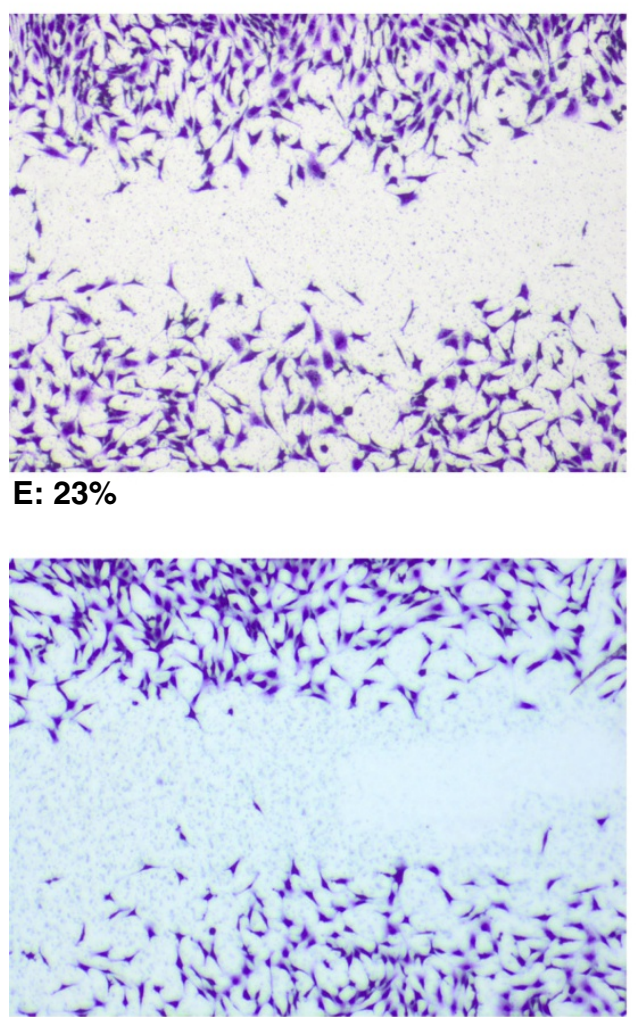

G: $3.2 \%$

Figure 3 (See legend on next page.)

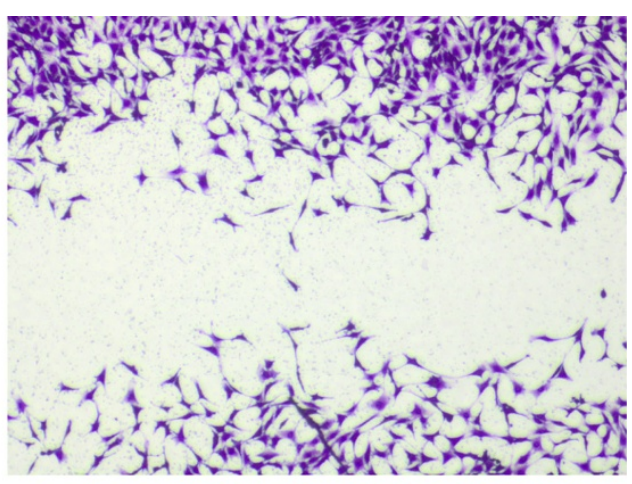

B: $0 \%$

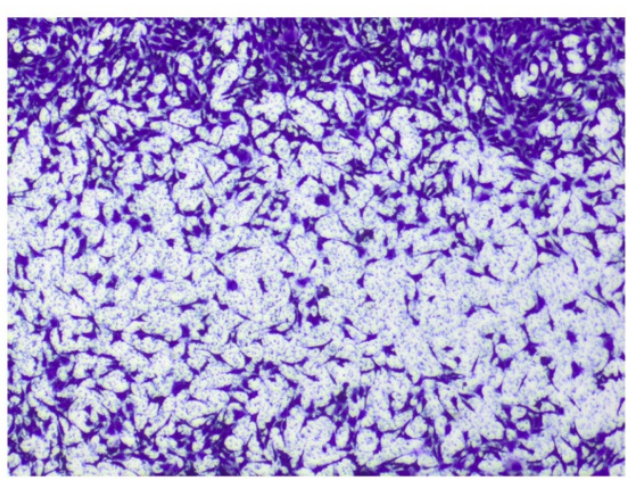

D: $77.2 \%$

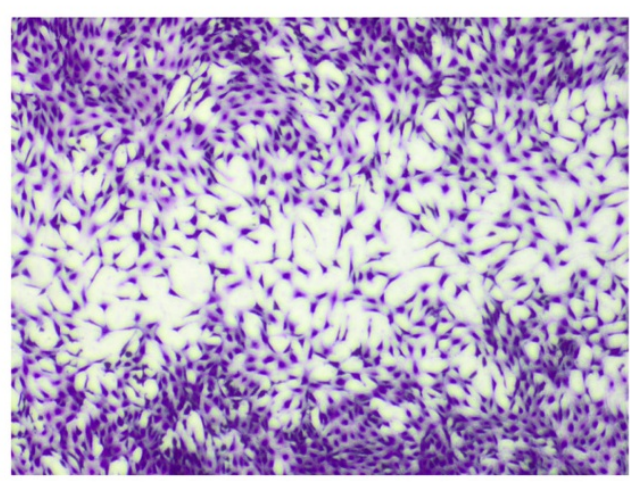

F: $69 \%$ 
The level of cellular fill within the wound area in response to substances was compared to the wound-fill response in the presence of $2 \%$ FCS as negative control. Density of cells in the controls without a wound (confluent area) was $30.3 \pm 5.3 \%$ and was set as $100 \%$ wound closure. Percentage of cells in the wound area was $10.6 \pm$ 3.4, 20.4 \pm 6.0 and $5.7 \pm 1.6$ for $0712-1,0712-2$ and 0712-3, respectively (Figure 2A). In wound field of positive control (5\% FCS) were $21.4 \pm 6.4 \%$ cells. Substances 0712-1 (succussed solvent) as well as 0712-2 (remedy) exerted significant effects $(\mathrm{p}<0.001)$ and closed the wound to $22.1 \pm 6.4 \%$ and $59.5 \pm 11.4 \%$. The level of wound closure by remedy (0712-2) was about twice the value of succussed solvent (0712-1). This difference in the wound filling effect between $0712-1$ and $0712-2$ was significant $(\mathrm{p}<0.001)$. However, unsuccussed solvent $(0712-3)$ filled the wound only by $3.7 \pm 0.8 \%$. Positive control 5\% FCS caused a $63 \pm 9.5 \%$ wound closure (Figure 2B).

The effect of substances $0712-1,0712-2$ and $0712-3$ on the closure of wounded area was investigated only in dilutions of 1:100 and 1:1000, because of the possible influence of $2.2 \%$ ethanol at 1:10 dilution. All three substances diluted 1:1000 exhibited only a negligible effect on wound filling, being between $4.2 \%$ and $6.3 \%$ (data not shown). One representative set of microphotographs on the wound healing effect of substances from three independent experiments is shown in Figure 3. In the chemotaxis migration assay as well as in the wound closure assay, succussed solvent (0712-1) showed a promoting effect on the closure of wound field. The investigated remedy (0712-2) filled the gap between the cells comparable to the positive control (5\% FCS) and we could establish its promoting effect on wound closure in comparison to the reduced fill rate of the control.

In vivo effectiveness of low potency homeopathic remedies containing arnica, marigold, St. John's wort or comfrey on wound healing has been reported in humans $[14,15]$. However, experimental studies were mainly based on animal models [32-34]. The concentrations of homeopathic remedies in the above mentioned studies ranged from $1 \mathrm{x}, 4 \mathrm{x}, 12 \mathrm{x}, 5 \mathrm{c}, 6 \mathrm{c}$ up to $1 \mathrm{M}$. Homeopathic remedies of Calendula and Hypericum applied were in the range of mother tincture (1x) in a rat model [33], but even Arnica $12 x$ showed positive influence on wound healing in rats [32]. In one trial Arnica $4 x$ (10 pills, 3 times per day) was equivalent to diclofenac (50 mg, 3 times per day) for wound irritation yet, not pain reduction after foot surgery [15]. Patients taking perioperative homeopathic Arnica montana $(5 \mathrm{c}-1 \mathrm{M})$ exhibited statistically significant less postoperative ecchymosis compared to placebo in a double blind clinical trial [14], but this effect could not be confirmed in a double blind trial conducted by others [17]. According to the available literature in medical databases the wound-healing effect of homeopathic remedies in in vitro models are scare or lacking. Bressler et al who studied the effect of Calendula officinalis $3 \mathrm{c}$ and low level laser therapy on wound healing in human skin fibroblasts described an accelerating effect on wound closure and increased cell viability by Calendula. Effective skin penetration ability of a remedy is an important factor for topical response and wound healing. It was reported that low concentrated Arnica preparations increased permeation through porcine skin [35] as well as human skin in vitro [36].

Several natural products have been shown to effectively accelerate wound healing [7] at pharmacological concentrations. The active constituents of these plants are mainly flavonoids, polyphenols, sesquiterpenes, essential oils, and tannins among other constituents [2]. The antioxidant, antiinflammatory effects exerted may be attributed to their wound healing effectiveness [37-39]. A mother tincture from Arnica montana exerted inhibition of 5-lipoxygenase/ cyclooxygenase in in vitro experiments [40] and even at concentrations of $6 c$ [13] and 4x [34] anti-inflammatory activity was shown in the carrageenan-induced rat paw oedema. Therefore the question of concern is whether low potency homeopathic remedies can exert biological effects in experimental cell models. This hypothesis is in line with the findings of our study where the final effective wound filling concentrations were $289 \mathrm{ng} / \mathrm{ml}$ of Arnica montana, $28.9 \mathrm{ng} / \mathrm{ml}$ Calendula officinalis, $89.4 \mathrm{ng} / \mathrm{ml}$ Hypericum perforatum and $0.823 \mathrm{ng} / \mathrm{ml}$ Symphytum officinalis expressed in dry weight of single herbs in the examined remedy (0712-2). It has been reported, that compounds at high dilutions/low concentrations could exert different biological activity. TNF- $\alpha$ up to $100 x$ from $100 \mathrm{ng} / \mathrm{ml}$ elevated the level of $\mathrm{H}_{2} \mathrm{O}_{2}$ in SK-N-SH neuroblastoma cells [30], arsenic of decimal and centesimal dilutions exerted effect in the rats [41], histamine dilutions ranging between $15-19 \mathrm{c}$ from $1 \mathrm{mg} / \mathrm{ml}$ inhibited human basophil degranulation [42]. In addition, normal and 
human leukemia T-lymphocytes responded to cadmium chloride at low doses (nM- $\mu \mathrm{M} ; 0.2-200 \mathrm{ng} / \mathrm{ml})$ [43]. Based on this it could be speculated, that the wound closure effect of the homeopathic remedy 0712-2 in NIH 3T3 fibroblasts may be due to the exerted properties of active ingredients at low concentrations.

In experiments with homeopathic preparations difficulties with the reproducibility even of in vitro models are known [44]. The present findings need to be confirmed in further studies before the chemotaxis and wound closure (scratch) model can be used to investigate various questions of interest in the in vitro research of homeopathic remedies. In the present study we described the in vitro wound closure effect of preparation $0712-2$ on one cell type (NIH 3T3 fibroblasts) involved in the overall wound healing process. Final proof as wound healing remedy can only be done by in vivo studies.

\section{Conclusions}

In this study we showed (i) that the in vitro wound model used was sensitive enough to observe effects of substances at low potency homeopathic concentrations and therefore could be further exploited for the development of an useful in vitro model.

We (ii) investigated the contribution of proliferation and migration towards the resulting wound fill by the remedy (0712-2). Its promoting wound filling effect could be related to the increased cell migration without an increased mitotic activity of cells.

\section{Competing interests}

The authors declare that they have no competing interests.

\section{Authors' contributions}

$\mathrm{KH}$ and RS are responsible for the study design, analysis and data interpretation as well as the manuscript preparation. $\mathrm{KH}$ conducted the assays and analyses. SB performed the statistical evaluations and helped with the draft of manuscript. MR and JM participated in data analysis and drafted the manuscript. All authors read and approved the final manuscript.

\section{Acknowledgements}

This work was partly funded by the Research Department of Similasan AG (Jonen, Switzerland). Interpretation of results was the prerogative of the authors. Publication of results was to occur regardless of the outcome.

\section{Author details \\ ${ }^{1}$ Institute for Complementary Medicine, University Hospital Zurich, Raemistrasse 100, Zurich 8091, Switzerland. ${ }^{2}$ University Medical Center Hamburg-Eppendorf, University Cancer Center Hamburg, Hubertus Wald Tumor Center, Martinistrasse 52, Hamburg 20246, Germany. ${ }^{3}$ Institute of Complementary Medicine KIKOM, University of Bern, Imhoof-Pavillon, Insel-Spital, Bern 3010, Switzerland. ${ }^{4}$ Center for Integrative Medicine, University of Witten/Herdecke, Gerhard-Kienle-Weg 4, Herdecke 58313, Germany. ${ }^{5}$ Society for Cancer Research, Kirschweg 9, Arlesheim 4144 , Switzerland.}

Received: 30 January 2012 Accepted: 8 July 2012

Published: 18 July 2012

\footnotetext{
References

1. Singer AJ, Clark RA: Cutaneous wound healing. N Engl J Med 1999, 341:738-746.
}

2. De Fatima A, Modolo LV, Conegero Sanches AC, Porto RR: Wound healing agents: The role of natural and non-natural products in drug development. Mini Rev Med Chem 2008, 8:879-888.

3. Gal P, Toporcer T, Grendel T, Vidova Z, Smetana K Jr, Dvorankova B, Gal T, Mozes S, Lenhardt L, Longauer F, Sabol M, Sabo J, Backor M: Effect of Atropa belladonna L. on skin wound healing: Biomechanical and histological study in rats and in vitro study in keratinocytes, 3T3 fibroblasts, and human umbilical vein endothelial cells. Wound Repair Regen 2007, 17:378-386.

4. Goldman RS, de Freitas PCD, Oga S: Wound healing and analgesic effect of crude extracts of Symphytum officinale in rats. Fitoterapia 1985, 66:323-329.

5. Leu S, Havey J, White LE, Martin N, Yoo SS, Rademaker AW, Alam M: Accelerated resolution of laser-induced bruising with topical $20 \%$ arnica: a rater-blinded randomized controlled trial. Br J Dermatol 2010, 163:557-563.

6. Chadran PK, Kuttan R: Effect of Calendula officinalis flower extract on acute phase proteins, antioxidant defense mechanism and granuloma formation during thermal burns. J Cli Biochem Nutr 2008, 43:58-64.

7. Reuter J, Merfort I, Schempp CM: Botanicals in dermatology. An evidencebased review. Am J Clin Dermatol 2010, 11:247-267.

8. Fronza M, Heinzmann B, Hamburger M, Laufer S, Merfort I: Determination of the wound healing effect of Calendula extracts using the scratch assay with 3T3 fibroblasts. J Ethnopharmacol 2009, 126:463-467.

9. Lavagna SM, Secci D, Chimenti P, Bonsignore L, Ottaviani A, Bizzari B Efficacy of Hypericum and Calendula oils in the epithelial reconstruction of surgical wounds in childbirth with caesarean section. Farmaco 2001, 56:451-453.

10. Dikmen $M$, Oztürk $Y$, Sagratini G, Ricciutelli M, Vittori S, Maggi F: Evaluation of the wound healing potentials of two subspecies of Hypericum perforatum on cultured NIH3T3 fibroblasts. Phytother Res 2011, 25:208-214.

11. Ernst E, Pittler MH: Efficacy of homeopathic arnica. Arch Surg 1998, 133:1187-1190.

12. Balzarini A, Felisi E, Martini A, De Conno F: Efficacy of homeopathic treatment of skin reactions during radiotherapy for breast cancer: a randomised, double-blind clinical trial. Br Homeopathic J 2000, 89:8-12.

13. Macedo SB, Ferreira LR, Perrazzo LL, Tavarea-Carvalho JC: Antiinflammatory activity of Arnica montana $6 \mathrm{cH}$. Preclinical study in animals. Homeopathy 2004, 93:84-87.

14. Seeley BM, Denton AB, Ahn MS, Maas CS: Effect of homeopathic Arnica Montana on bruising in face-lifts: results of a randomized, double-blind, placebo-controlled clinical trials. Arch Facial Plast Surg 2006, 8:54-59.

15. Karow JH, Abt HP, Fröhling M, Ackermann H: Efficacy of Arnica montana D4 for healing of wounds after Hallux valgus surgery compared to diclofenac. J Altern Complement Med 2008, 14:17-25.

16. Stevinson C, Devaraj VS, Fountain Barber A, Hawkins S, Ernst E: Homeopathic arnica for prevention of pain and bruising: randomized placebo-controlled trial in hand surgery. J R Soc Med 2003, 96:60-64.

17. Kotlus SB, Heringr MD, Drydem MR: Evaluation of homeopathic Arnica montana for ecchymosis after upper blepharoplasty: a placebocontrolled, randomized, double-blind study. Ophthal Plast Reconstr Surg 2010, 26:395-397.

18. Bresler A, Hawkins D, Raziog R, Abrahamse H: Effect of low level laser therapy and Calendula officinalis $3 \mathrm{CH}$ on wound healing in human skin fibroblasts. Ind J Res Hom 2008, 2:7-15.

19. Liang CC, Park AY, Guan JL: In vitro scratch assay: a convenient and inexpensive method for analysis of a cell migration in vitro. Nat Protoc 2007, 2:329-333.

20. German Homeopathic Pharmacopoiea: Wissentschaftliche Verlagsgesellschaft mbH Stuttgart: MedPharm Scientific Publishers; 2010.

21. Hostanska K, Melzer J, Amon A, Saller R: Suppression of interleukin (IL)-8 and human beta defensin-2 secretion in LPS-and /or IL-1ß-stimulated epithelial A549 cell by a herbal formulation against respiratory infections (BNO 1030). J Ethnopharmacol 2011, 134:228-233.

22. Hardonk MJ, Harms G: The use of 5'-Bromodeoxyuridine in the study of cell proliferation. Acta Histochemica 1990, Suppl.39:99-108.

23. Hostanska K, Nisslein T, Freudenstein J, Reichling J, Saller R: Inhibitory effect of an isopropanolic extract of black cohosh on invasiveness of MDA-MB 231 human breast cancer cells. In vivo 2007, 21:349-356.

24. Selinummi J, Seppala J, Yli-Harja O, Puhakka JA: Software for quantification of labeled bacteria from digital microscope images by automated image analysis. Biotechniques 2005, 39:859-863. 
25. Fukaya K, Miyazaki M, Pu H, Katayama B, Inoue Y, Ohashi R, Nakamura C, Namba M: Pyruvate alleviates toxic effect of ethanol on cells in culture. Arch Toxicol 1997, 71:651-654.

26. Gradl G, Faust D, Oesch F, Wieser RJ: Density-dependent regulation of cell growth by contactinhibin and the contactinibin receptor. Curr Biol 1995, 5:526-535.

27. Graham MF, Diegelman RF, Cohen IK: An in vitro model of fibroplasia: simultaneous quantification of fibroblast proliferation, migration, and collagen synthesis. Proc Soc Exp Biol Med 1984, 176:302-308.

28. Lauffenburger DA, Horwitz AF: Cell migration: a physically integrated molecular process. Cell 1996, 84:359-369.

29. Engström W: Differential effects of epidermal growth factor (EGF) on cell locomotion and cell proliferation in a cloned human embryonal carcinoma-derived cell line in vitro. J Cell Sci 1986, 86:47-55.

30. Carmine TC: Effects of high potencies of tumor necrosis factor alpha on $\mathrm{H}_{2} \mathrm{O}_{2}$ production in cultured neuroblastoma cells by enhanced luminoldependent chemiluminiscence (ECL). Br Homeopatic J 1997, 86:67-72.

31. Paul D, Lipton A, Klinger I: Serum factor requirements of normal an simian virus 40-transformed $3 \mathrm{~T} 3$ mouse fibroblasts. Proc Nat Acad Sci USA 1971, 68:645-652.

32. Niebauer GW, Dorcsi M, Pfeil L: Die Wirkung von homöopathischen Arnica D und Actihaemyl auf die Wundheilung im Tierexperiment. Prakt Tierarzt 1980, 61:128-132.

33. Rao SG, Udupa AL, Udupa SL, Rao PGM, Rao G, Kulkarni DR: Calendula and Hypericum: two homeopathic drugs promoting wound healing in rats. Fitoterapia 1991, 62:508-510.

34. Conforti A, Bellavite P, Bertani S, Chiarotti F, Menniti-Ippolito F, Raschetti R: Rat models of acute inflammation: a randomized controlled study on the effects of homeopathic remedies. BMC Complement Altern Med 2007, 7:1.

35. Wagner S, Suter A, Merfort I: Skin penetration studies of Arnica preparations and of their sesquiterpene lactones. Planta Med 2004, 70:897-903.

36. Tekko IA, Bonner MC, Bowen RD, Williams AC: Permeation of bioactive constituents from Arnica montana preparations through human skin in vitro. J Pharm Pharmacol 2006, 58:1167-1176.

37. Preethi KC, Kuttan G, Kuttan R: Antioxidant potential of Calendula officinalis flowers in vitro and in vivo. Pharm Biol 2006, 44:691-697.

38. Thring TSA, Hili P, Naughton DP: Anti-collagenase, anti-elastase and antioxidant activities of extracts from 21 plants. BMC Complement Altern Med 2009, 9:27.

39. Mathew A, Taranalli AD, Torgal SS: Evaluation of anti-inflammatory and wound healing activity of Genziana lutea rhizome extracts in animals. Pharm Biol 2004, 42:8-12.

40. Jäggi R, Würgler U, Grandjean F, Weiser M: Dual inhibition of 5lipoxygenase/cyclooxygenase by a reconstituted homeopathic remedy; possible explanation for clinical efficacy and favourable gastrointestinal tolerability. Infamm Res 2004, 53:150-157.

41. Cazin JC, Cazin M, Gaborit JL, Chaoui A, Boiron J, Belon P, Cherruault Y, Papapanayotou C: A study of the effect of decimal and centesimal dilutions of arsenic on the retention and mobilization of arsenic in the rat. Human Toxicol 1987, 6:315-320

42. Belon P, Cumps J, Ennis M, Mannaioni PF, Sainte-Laudy J, Roberfroid M, Wiegant FAC: Inhibition of human basophil degranulation by successive histamine dilutions: Results of a European multi-centre trial. Inflamm Res 1999, 48(Suppl.1):S17-S18.

43. Wälchli C, Baumgartner S, Bastide M: Effect of low doses and high homeopathic potencies in normal and cancerous human lymphocytes: An in vitro isopathic study. J Altern Complement Med 2006, 12:421-427.

44. Witt CM, Bluth M, Albrecht H, Weisshuhn TER, Baumgartner S, Willich SN: The in vitro evidence for an effect of high homeopathic potencies- A systematic review of the literature. Complement Therapies in Med 2007, 15:128-138.

doi:10.1186/1472-6882-12-100

Cite this article as: Hostanska et al: A homeopathic remedy from arnica, marigold, St. John's wort and comfrey accelerates in vitro wound scratch closure of NIH 3T3 fibroblasts. BMC Complementary and Alternative Medicine 2012 12:100.

\section{Submit your next manuscript to BioMed Central and take full advantage of:}

- Convenient online submission

- Thorough peer review

- No space constraints or color figure charges

- Immediate publication on acceptance

- Inclusion in PubMed, CAS, Scopus and Google Scholar

- Research which is freely available for redistribution 